\title{
Board Eligible
}

National Cancer Institute

\section{Source}

National Cancer Institute. Board Eligible. NCI Thesaurus. Code C54655.

Specifies that a physician has completed the requirements for admission to a medical specialty board examination but has not taken and passed that examination. 